\title{
Arrested Development? UNHCR, ILO, AND THE REFUGEES' RIGHT TO WORK
}

\author{
AdÈLE GARNIER
}

\begin{abstract}
This article contributes to literature assessing power dynamics in the emerging global migration governance. Drawing on Barnett and Finnemore's analysis of bureaucratic culture in international organizations, it investigates inter-agency cooperation between the Office of the United Nations High Commissioner for Refugees and the International Labour Organization in the promotion of refugees' right to work in the last two decades. While the mandate and activities of both organizations appear to significantly intersect in the promotion of this right, practical constraints related to states' diverging interests, differences in institutional structure, and discursive ambivalence in the situation of the refugee worker limit coordination and effectiveness.
\end{abstract}

\section{Résumé}

Cet article contribue aux études des relations de pouvoir dans la gouvernance mondiale des migrations. S'inspirant des travaux de Barnett et Finnemore sur la culture bureaucratique des organisations internationales, il analyse la coopération, lors des deux dernières décennies, entre le Haut-Commissariat aux Réfugiés des Nations Unies et l'Organisation Internationale $d u$ Travail en matière de promotion du droit au travail des réfugiés. Le mandat et les activités des deux organisations semblent faire preuve de complémentarité dans la promotion de ce droit. Cependant, des contraintes pratiques liées aux intérêts divergents des États, des différences de structure institutionnelle au sein des deux organisations ainsi que les ambivalences de leur discours sur le réfugié travailleur limitent la coordination et l'efficacité entre les deux organisations.

\section{Introduction}

7 his article explores the cooperation of the Office of the United Nations High Commissioner for Refugees (UNHCR) and the International Labour Organization (ILO) in the promotion of refugees' right to work during the last two decades. It offers empirical insights into an example of collaboration between international organizations that has yet to attract much attention. It also aims to contribute to literature critically assessing power dynamics in the emerging global migration governance with a focus on its institutional dimension. The article shows that, in spite of significant potential for both United Nations agencies to jointly promote refugees' right to work, achievements in the 21st century have remained limited. An explanation is offered. While the significance of an inauspicious international environment cannot be understated, pathologies related to the bureaucratic culture of international organizations also weakened joint achievements.

The next section develops the theoretical framework. The article subsequently points to intersections between the ILO's and the UNHCR's mandates to promote refugees' right to work and presents their joint activities on the issue. Three challenges to effective cooperation are then presented: limited state interest in and institutional competition over the focus of UNHCR-ILO cooperation, organizational obstacles within both agencies, and broader lack of visibility 
of the refugee worker. The second and the third challenges are related to what Barnett and Finnemore label "bureaucratic pathologies." The conclusion discusses the significance of the findings.

\section{Exploring Interagency Cooperation in Emerging Global Migration Governance}

As Geiger and Pécoud recently noted, although international organizations (IOs) have become considerably more significant in the politics of migration since the end of the Cold War, research focusing specifically on IOs in this field is still emerging. ${ }^{2}$ The International Organization for Migration (IOM) and the UNHCR have attracted most scholarly attention. ${ }^{3}$ In contrast, literature on the ILO is limited, despite the ILO's engagement with migration policy since its establishment in 1919, reflected in the migration governance suggestions of the ILO's first director general, Albert Thomas. 4 This research can therefore shed light onto the IO that until the end of 2014 heads the Global Migration Group, one of the main forums of emerging global migration governance. 5

In addition, the article adds to the small number of studies exploring interrelations between IOs in this field. Among these studies, Newland suggests a set of patterns of competition, cooperation, and transformation among IOs. ${ }^{6}$ Betts focuses on the UNHCR's response to an increasingly complex and competitive global governance architecture in which its leadership over the global refugee regime is challenged.7 Drawing on a governmentality framework, Geiger shows how IOs such as the IOM cooperate with European Union (EU) institutions to develop migration regulations at the EU periphery. ${ }^{8}$ Focusing on the UNHCR's and IOM's joint legitimization of states' migrant return policies, Koch highlights the significance of state interest in inter-IOs cooperation and the joint capacity of the two IOs.9 Similarly, this article will address state interest and IO capacity, albeit in a different international and institutional environment. To this purpose, I shall show the relevance of Barnett and Finnemore's discussion of bureaucratic culture and "bureaucratic pathologies" in IOs in the analysis of interagency cooperation.

Barnett and Finnemore are critical of the functionalist assumption of most international relations scholarship, which focuses on why IOs exist rather than on how they work. Drawing on literature on organizations and on Weber, they argue that states grant IOs legitimacy because rational bureaucracies make impersonal rules on cross-border issues. Realist and neoliberal institutionalist accounts respectively contend that IOs gain authority primarily because of their power over material resources and information. In contrast, Barnett and Finnemore state that
IOs gain authority because "they use [it] to orient action and create social reality ... [transforming] information into knowledge."1o IOs not only define norms and categories in international law, they also interpret the meaning of these categories and promote their worldwide diffusion. Yet what makes IOs efficient as impersonal, rational bureaucracies also fosters internal problems, which Barnett and Finnemore refer to as "bureaucratic pathologies": "We call 'pathologies' those dysfunctions that are attributable to bureaucratic culture and internal bureaucratic pressures and that lead the IO to act in a manner that subverts its selfprofessed goals." ${ }^{11}$ Accordingly, IOs can create norms that contradict each other ("irrationality of rationalization"); tolerate breaches of long-established norms ("normalization of deviance"); focus so much on universal standard as to ignore the local context ("bureaucratic universalism"); isolate themselves from scrutiny and feedback ("insulation"); and are riddled with internal struggles ("cultural contestation"). ${ }^{12}$ Bureaucratic expansion can fuel such pathologies, and so can factors external to IOs, such as funding shortages. ${ }^{13}$ In the following empirical analysis, I intend to show that bureaucratic pathologies not only weaken the authority of single IOs but can also impede inter-agency cooperation. Barnett and Finnemore's framework has yet to be used in this perspective, which could fruitfully contribute to global migration-governance literature. I shall return to this last point in the conclusion.

\section{Intersections in UNHCR and ILO Mandates and Framework for Inter-Agency Cooperation}

The right to work is protected in binding universal human rights treaties, most significantly in articles 6 to 8 of the International Covenant on Economic, Social and Cultural Rights (ICESCR), while the International Covenant on Civil and Political Rights and other core UN human rights treaties such as the Convention on the Elimination of all forms of Racial Discrimination, the Convention on the Elimination of all Forms of Discrimination against Women, and the Convention on the Rights of the Child protect against forced labour and slavery. ${ }^{14}$ Given that all UN agencies promote compliance with human rights treaties, it can be said that the UNHCR and the ILO mandates intersect, as they share this normative basis.

Refugee rights are more specifically defined in the Convention relating to the Status of Refugees (the Refugee Convention). ${ }^{15}$ The Refugee Convention stipulates nondiscrimination of refugees in wage-earning employment (article 17; the convention recommends that refugees be treated like nationals as much as possible), self-employment (article 18), and the liberal professions (article 19). More than 20 countries impose restrictions on article 17. Among them, 
a dozen consider the article to be a recommendation, not an obligation. ${ }^{16}$ Because of the Refugee Convention's obligations, refugees have been excluded from the remit of the 1990 UN Convention on the Rights of All Migrant Workers and Their Families. ${ }^{17}$ The UNHCR is mandated to supervise the application of the Refugee Convention (article 35). The Refugee Convention provisions on the right to work do not apply to asylum seekers, as they are not recognized refugees. ${ }^{18}$

The ILO is the only tripartite organization of the UN system. Its normative instruments are drafted, adopted, and supervised by representatives of governments, employers, and unions, yet ratification of adopted instruments is done by government representatives only. While the ILO also focuses on the right to work, the bulk of its conventions and standards address rights at work and aim to ensure that work is fair and decent. ILO conventions and standards apply to all workers, with no discrimination between nationals and foreign nationals. Several conventions deal specifically with the rights of migrant workers, ${ }^{19}$ yet conventions and standards dealing specifically with these rights have very low levels of ratification. ${ }^{20}$ Nonetheless, the ILO 1998 Declaration of Fundamental Principles and Rights at Work states four core principles applying to all states, regardless of their ratification of related instruments: freedom of association and effective recognition of the right to collective bargaining; elimination of all forms of forced or compulsory labour; effective abolition of child labour; and elimination of discrimination in respect of employment and occupation. A specific supervisory mechanism for non-ratifying states accompanies these principles. ${ }^{21}$

Thus, in addition to the common normative base shared by the UNHCR and the ILO (universal human rights treaties), it can be said that there is a division of labour in the setting and supervision of norms. The UNHCR monitors compliance with the non-discrimination of refugees in accessing work, as defined in the Refugee Convention, whereas the ILO's conventions and standards aim to ensure that all workers, including refugees, are treated fairly and involved in "social dialogue." This division of labour does not preclude joint activities between the UNHCR and the ILO.

Both agencies launched joined projects to identify and foster income-generating activities for refugees in Somalia and Sudan in the early 1980s. The Somali project targeted women and children who relied almost entirely on humanitarian assistance in refugee camps, while the Sudanese project aimed to help both refugees and local populations (men were the primary group of concern) broaden economic activities in poor agricultural regions. ${ }^{22}$ In both cases, the UNHCR requested the ILO's assistance and provided funding aside from other donors. While the two projects targeted only a small minority of potential beneficiaries, they translated for several years into effective income-generation and skills-broadening for participants. Long-term sustainability was eventually compromised by the outbreak of civil war in Somalia and lack of long-term financial support in Sudan.

As these projects were getting off the ground, in 1983, ILO director general Francis Blanchard and high commissioner for refugees Poul Hartling signed a memorandum of understanding (MoU). ${ }^{23}$ The UNHCR signed MoUs with the World Food Programme (WFP) and the IOM, with whom it cooperates steadily, only in 1985 (revised in 2002) and 1997 respectively. ${ }^{24}$ While acknowledging the UNHCR's refugeeprotection mandate and the ILO's social-justice mandate, the UNHCR-ILO MoU mentions "common areas of concern" in the treatment and assistance of refugees. Both IOs pledge to jointly work on:

- protecting the socio-economic rights of refugees and developing new standards giving consideration to the vulnerability of refugees;

- fostering the socio-economic integration of refugees in their country of residence, and of returning refugees in their countries of origin;

- building refugee skills and developing job opportunities, on the basis of early ILO assistance to UNHCR and mutual funding agreements;

- exchanging information between field offices regarding refugee assistance;

- exchanging policy information at headquarter level.

It can be argued that the MoU promisingly expanded upon the ILO and the UNHCR's joint normative basis to support refugees' right to work while fostering their rights at work, even though the latter aspect is less specific in the agreement than the former. Over the following decades, the focus of both IOs experienced significant transformations. From the 1980s, the UNHCR became increasingly involved in refugee repatriation and took responsibility for internally displaced persons (IDPs), so that its involvement in the socio-economic integration of returning refugees and IDPs gained prominence. The role of the UNHCR in humanitarian relief expanded considerably, transforming the IO into a leading agency in the field. ${ }^{25}$ Amid institutional reforms centred on the promotion of the Decent Work agenda and aiming to increase the ILO's relevance in a context of globalization. $^{26}$ the ILO also expanded its labour-supporting activities in post-conflict situations. ${ }^{27}$ In parallel, from the 2000 both IOs were involved in development of a rightsbased discourse on migration, the UNHCR by focusing on rights in the context of "mixed migratory flows" while the ILO Governing Body mandated the organization to develop a plan of action for migrant workers in $2004 .{ }^{28}$ We shall return to the significance of these broad developments for 
the authority of both IOs over the promotion of refugees' right to work after we have examined their joint activities in the last two decades.

\section{UNHCR-ILO Activities in the 21st Century}

According to UNHCR and ILO global reports of activities, as well as specific project documentation, the main focus of UNHCR-ILO cooperation in promotion of refugees' right to work in the 21st century is the transition from relief to development. Included are activities to prepare refugees for economic reintegration into their country of origin and to assist refugees and IDPs once they have returned to their country or location of origin. This reflects opportunities to jointly promote refugees' right to work in the field delineated in the 1983 UNHCR-ILO MoU.

From 2000, the two IOs promoted micro-finance, taking into consideration the financial vulnerability of many refugees, especially female refugees, who wish to set up businesses. Activities included the organization of training workshops in field offices, publication of the manual Introduction to Micro-Finance in Conflict-Affected Communities, and production of policy guidelines on micro-finance. ${ }^{29}$ While the UNHCR had used micro-finance before cooperating with the ILO, its use expanded considerably from 2000 in the context of the UNHCR's increased focus on refugee livelihoods. According to Azorbo, as of 2011 the UNHCR used micro-finance programs in 45 per cent of its country operations. ${ }^{30}$ The IO adopted a memorandum of understanding with the leading micro-finance institution, the Grameen Bank, while continuing to work with the ILO. Yet Azorbo notes that training capacity remains very limited, questioning the practical impact of micro-finance advocacy, and observes that the UNHCR has not released a systematic evaluation of its micro-finance activities.

Between 2003 and 2007, Italy provided almost US\$1 million in funding to support establishment of the "ILOUNHCR Partnership through Technical Cooperation: Socio-economic Integration of Refugees, Returnees and Internally Displaced persons." 31 This partnership was endorsed at the top of the agencies. In November 2004, ILO director general Juan Somavia and high commissioner for refugees Ruud Lubbers signed a statement aiming for a "strengthened partnership" over the transition from relief to development so as to foster sustainable livelihoods and poverty reduction. A working group composed of ILO sections focusing on crisis and reconstruction (InFocus and IFP/CRISIS, later renamed ILO/CRISIS) and the UNHCR's Reintegration and Local Settlement Section were set up to guide and review projects as well as liaising with other departments and both headquarters. ${ }^{32}$ The partnership received more than US\$2 million in funding and intervened in 15 countries in Africa, Latin America, Central and South Asia, and Southeastern Europe ${ }^{33}$ The ILO also released a review of its above-mentioned projects for African refugees in the 1980s, to "guide future work" by the ILO and other agencies on the issue as well as "revive the [ILO]'s institutional memory" concerning refugees. 34

To give an example of the ILO-UNHCR partnership's projects, in the Maratane refugee camp in Mozambique, an ILO consultant, with the support of an ILO team based in Zambia and of ILO/CRISIS in Geneva, aimed to develop "the socio-economic empowerment of women in the refugee community" of the camp in the early 1980s. A small group of local women and men was first selected to become trainers in business skills. The consultant and the trainer then focused on a group of women, who often had no previous entrepreneurial experience, to participate in a two-week workshop to develop business plans. In a climate of gender-based discrimination towards women taking up jobs, workshops were also organized with men and women to discuss gender stereotypes in the economic context. 35 Collaboration with local governments, and especially with financing institutions, was also sought. According to a UNHCR press release from 2007 , the project was well perceived by participants and expanded to the entire Maratane camp, where self-reliance increased. While the original ILO report announces a three-year monitoring period, the 2007 UNHCR press release does not mention the ILO anymore, self-reliance activities now being offered by World Relief International. ${ }^{6}$ The promised evaluation after the threeyear period of implementation could not be located.

The Mozambican project added innovation to UNHCR practice, especially the training of local trainers among refugees. ${ }^{37}$ Further innovation occurred from the UNHCR perspective in Liberia: the UNHCR local field office worked with an ILO consultant to foster employment of returning refugees. In the face of very high unemployment in postwar Liberia, employment in the informal economy was promoted with use of ILO community-based training methods. ${ }^{38}$ In 2007, ILO/CRISIS expressed high hopes for the partnership, stating, "Potentially this program will be able to serve the entire refugee population assisted by UNHCR as it sets the framework for the rapid deployment of ILO livelihood experts to UNHCR's country operations ... This project has proven its effectiveness in coupling ILO's expertise in livelihoods and sustainable development with UNHCR's expertise and mandate to provide protection and assistance to refugees, returnees and at times, IDPs, and to find durable solutions to their plight." 39

From 2007, however, and alongside the above-mentioned micro-finance activities, UNHCR-ILO technical cooperation promoting refugees' right to work appeared to occur 
primarily in the context of the UNHCR's Strengthening Protection Capacity Projects (SPCPs). SPCPs started in 2005 and were funded largely by the European Union. While SPCPs took place in a dozen countries, the ILO seldom appears to play a prominent role in project design and is generally one partner among many. This is not surprising, as SPCPs not only aim to improve refugees' self-reliance but also to strengthen capacity of refugee-hosting countries to provide protection at the legal and institutional level. One exception is the SPCP in Thailand, which had a dedicated livelihood component designed jointly by the UNHCR and the ILO. The project first identified issues limiting the economic participation of Burmese refugees, then launched a pilot project in the Mae La camp (the largest refugee camp on the Thailand/Myanmar border) aiming to foster vegetable production, then sales of the produce with development of business strategies with a few hundred refugees..$^{40}$

Further ILO involvement in livelihood activities in the Mae La camp is not documented; however, ILO training material, such as on the community-based development of business skills, is used by NGOs now pursuing livelihood activities in cooperation with UNHCR. ${ }^{41}$ However, the ILO does not feature prominently in the increasing number of UNHCR publications showing renewed IO interest for the issue of refugee livelihoods besides the SPCPs. For instance, the UNHCR Global Strategy for Livelihoods for 2014-18 does not refer to previous ILO-UNHCR cooperation, nor does it quote ILO sources on the issue. In contrast, the UNHCR highlights its cooperation with the World Food Programme. ${ }^{42}$

To sum up, it appears that a sustained period of bilateral technical cooperation between the UNHCR and ILO (20037) entailed knowledge transfer and institutional innovation by the UNHCR in more than a dozen field projects worldwide, followed by a loosening of the partnership between the IOs and the absorption of their ties into wider, more multilateral projects. The dissemination of ILO knowledge to the UNHCR and other partners has occurred primarily through the use of ILO publications in the field, yet the contribution of the ILO does not appear to be much recognized beyond the field level.

This article considers that such an outcome was not inevitable. The UNHCR-ILO partnership might have expanded on the basis their shared normative base, early technical cooperation, and the $1983 \mathrm{MoU}$ providing a more specific framework for normative and technical cooperation. Therefore, the following section suggests explanations to the limits of the UNHCR-ILO cooperation in the promotion of refugees' right to work in the 21st century. Drawing on Barnett and Finnemore's analytical framework, it focuses first on the international environment before addressing dynamics within and between the two IOs.

\section{Challenges to UNHCR-ILO Cooperation}

Inauspicious International Environment: States' Lack of Interest and Institutional Competition

As Suhrke and Ofstad note, there has long been a "macrofunding gap" in the relief-development continuum. ${ }^{43}$ Donors' lines of funding for humanitarian and development aid are generally distinct. Additionally, funding is often more readily available for humanitarian projects than for reconstruction and rehabilitation. An ILO representative praised the UNHCR-ILO partnership in previous years at a UNHCR Executive Committee meeting in 2006, yet noted that important projects could not be completed as a result of a funding shortage. ${ }^{44}$ It is reasonable to suggest that such funding shortage reflects states' lack of political will to support refugees' right to work in this context. More broadly, the UNHCR's own attempts to lead in the relief-to-development issue since the late 1990s, most notably the Brooking Process and the Convention Plus initiative, were embraced neither by key multilateral institutions nor by a majority of states. While especially the United Nations Development Programme (UNDP) was, until the mid-20oos, wary of UNHCR's involvement in the development field, states of the Global South felt marginalized from the start in the Convention Plus process. ${ }^{45}$ Deschamp and Lohse note an increasing multilateral interest in relief-development linkages since 2008, with the design of a Framework for Ending Displacement in the Aftermath of Conflict by the UNHCR, the UNDP, and the Office for the Coordination of Humanitarian Affairs (OCHA), to which the ILO contributes alongside other IOs. Yet they conclude, "In regard to practice, principally reflected in the availability and predictability of funding to bridge the humanitarian-development gap ... things have not changed much for the better." 46

State-imposed controls on refugee mobility, and in some cases, on the right to work, in countries where ILO-UNHCR projects took place are equally problematic. In the UNHCRILO project on skill assessment in the Kakuma and Dabaab refugee camps in Kenya, refugees were neither allowed to leave the camps nor to work for a wage in the country. 47 Such restrictive measures prevent local integration of populations that should eventually repatriate, yet restrictions also maintain refugees in long-term survival situations while not decreasing tensions with local hosting communities. Change in regulations can also hamper self-reliance projects. In the Maratane camp project in Mozambique, the introduction of mobility control for refugees in a period of expansion of self-reliance caused a sudden swell in camp population and put pressure on resources. ${ }^{8}$ 


\section{Lack of Institutional Impact of Field Cooperation}

A difficult international environment should not imply per se that UNHCR and ILO do not have agency over the promotion of refugees' right to work. It has been argued that, since the early 20oos, the UNHCR has designed a relatively coherent strategy on refugee resettlement at the normative and operational level, and developed linkages with supranational and non-governmental agencies, even though this strategy has yet to significantly affect states' willingness to resettle refugees. ${ }^{49}$ In the case of the UNHCR-ILO partnership, however, it appears that the engagement of both IOs' headquarters has been only sporadic. Since 2004, the heads of both organizations have not released another joint statement on strengthened cooperation. This can contribute to explaining the invisibility of UNHCR-ILO fieldwork within each agency.

Tellingly, in an ILO study titled "Integrating Migration into Development Planning," Lucas observes a lack of data on the reintegration of refugees in their country of and on refugee employment in camps. The paper seems unaware of UNHCR work on the issue, and of ILO-UNHCR reports on their joint projects, such as in Mozambique and Kenya, as this research is not quoted.50 There is no evaluation of UNHCR-ILO projects by the agency's Policy Development and Evaluation Service (PDES), whereas there is a series of evaluations of UNHCR-WFP projects, as well as a management response. Among PDES's New Issues in Refugee Research reports, only one discusses potential links between the UNHCR and the ILO, arguing that both IOs could partner on the issue of domestic work..$^{51}$ Indeed, the ILO increased its focus on domestic work with the adoption of the Domestic Workers Convention 2011 (no. 189), and many urban refugees (especially women) work in the sector. ${ }^{2}$ Three years later, there is no evidence of joint activities on the issue.

Within the broader framework of global migration governance, UNHCR-ILO cooperation is not discussed in the documents released by either IO on the website of the Global Migration Group. ${ }^{33}$ Nor is it mentioned in UN documents presenting the view of the UN agencies involved in the 2013 High Level Dialogue on Migration and Development. ${ }^{4}$ The UNHCR-ILO cooperation therefore appears to be invisible not only within each agency but also to each other, and more broadly, to the emerging global migration-governance architecture.

Can "bureaucratic pathologies" contribute to explain disjunctures between fieldwork and headquarters and lack of reciprocal knowledge diffusion? The lack of influence of field offices on ILO and UNHCR headquarters is well known.55 Using Barnett and Finnemore's typology of bureaucratic pathologies, "bureaucratic universalism," as well as "cultural contestation" and "insulation" are apparent. According to former ILO employees Guy Standing and William R. Simpson, the ILO, which has experienced considerable reforms and thematic broadening over the last decades, has difficulty being a standard-setter, a technicalassistance organization, and a knowledge generator at once..$^{56}$ Former ILO director general Juan Somavia also regretted the ILO's lack of internal coherence as well as its tendency to resist external scrutiny. ${ }^{57}$ Wigley stresses that the UNHCR is simultaneously caught in a dynamic of permanent "shorttermism," focusing on the next crisis, while headquarters keeps producing guidelines that are not directly related to concerns in the field.$^{8}$ Standing and Wigley also point to the climate of intense competition within both agencies, which can disrupt efficient communication between the field and headquarters. Finally-and this is an issue not addressed by Barnett and Finnemore-staff casualization can limit dissemination of innovation within both institutions, given the significance of interpersonal relationships in the promotion of change within the two IOs.59

Yet there might also be "rational" bureaucratic reasons for the limits of the UNHCR-ILO partnership in promotion of refugees' right to work. In the context of intense bureaucratic competition for leadership over "relief-to-development" and of limited funding, the UNHCR may have opted to use the lowest-cost ILO resources (its publications) while increasing staff-based partnership with organizations perceived to deliver higher returns in the promotion of its refugee livelihoods strategy (the WFP and the UNDP). As the ILO focuses increasingly on issues such as the rights of all domestic workers, the ILO may also have so far considered it more cost-effective not to intensify cooperation on the specific issue of refugees' right to work. ${ }^{60}$

\section{The Broader Invisibility of the Refugee Worker}

A third issue limiting the visibility of UNHCR-ILO promotion of refugees' right to work is the lack of recognition of the refugee as a worker. While the transition from relief to development is essential in post-crisis situations, it seems that within both agencies linkages are missing between emphasis on the refugee's ability to provide for his or her basic needs (the transitory period) and forms of work that go beyond the threshold of survival. For instance, similarities between the refugee worker and the migrant worker could be explored. However, on the website of the ILO, there is no way to access ILO-UNHCR reports of activities via the specific search function of the ILO Labour Migration Branch (MIGRANT)'s webpage. ${ }^{61}$ One has to search via other ILO webpages, especially that of the Employment Policy Department (EMPLOYMENT), which has absorbed ILO/CRISIS. Reviewing the topics of ILO's International 
Migrants Working Papers (published regularly since 1995, totalling 118 issues so far), none of the papers' titles deals with refugees or, more broadly, forced migrants in the context of labour migration. Individual papers do address the issue as part of broader discussions. ${ }^{62}$

On the side of the UNHCR, a review of PDES's New Issues in Refugee Research (published regularly since 1999) and UNHCR evaluation reports shows that the refugee as a worker, or refugee labour, is barely ever the primary focus of either series. More often, refugee labour is discussed in reviews of refugees' social capital, livelihood approaches, reintegration in their country of origin, durable solutions, poverty reduction, and transition from relief to development. Exceptions are Colic-Peisker's paper on the labour integration of Bosnian refugees in Australia, Long's discussion of the labour migration and durable solutions, Umlas's review of urban refugees' right to work and UNHCR advocacy, and Ott's review of the labour market integration of resettled refugees, out of a corpus of 196 evaluations and 271 research papers. ${ }^{63}$

Nonetheless, it seems that the UNHCR is focusing increasingly on the diversity of situations of the refugee worker, as Ott's study shows. In part this the result of UNHCR responsiveness to NGO demands on the issue, even though NGOs deplore lack of implementation of this apparent conceptual shift. ${ }^{64}$ So far, a similar evolution is not observed at the ILO. ${ }^{65}$

These observations contribute to scholarship pointing at the historical association of the label of "refugee" with humanitarian crises, and its dissociation from economic activities, except when the latter are challenging the genuineness of the refugee (e.g., the pejorative character of the "economic refugee"). ${ }^{66}$ More conceptually, exclusive emphasis on promotion of livelihood strategies in utterly precarious situations (refugee camps and post-conflict societies where work is scarce) bears the risk of what Barnett and Finnemore label the "normalization of deviance," that is, in this case, the legitimization of a conception of labour that deviates from full recognition of the right to work. The UNHCR's broader focus on the refugee worker can contribute to prevent this normalization, and change in this respect within the ILO could encourage normative realignment and cooperation between both agencies.

\section{Conclusion}

The article has highlighted the potential and limits of UNHCR-ILO activities promoting refugees' right to work in the 21st century. It has uncovered a solid normative basis for cooperation and sustained technical collaboration in the field over several years, resulting in practical innovations and knowledge diffusion between both IOs and to other partners. Were this analysis to stop in 2007, one could argue, drawing on Barnett and Finnemore, that the UNHCR and the ILO were jointly reinforcing their authority as they appeared in harmony on norm definition (agreement about the population of concern and their rights, and division of labour to better assist them) while embracing norm diffusion between them and outwardly. Yet bureaucratic pathologies were already prevalent before 2007 , especially cultural contestation, bureaucratic universalism, and insulation. It can be assumed that these pathologies were exacerbated after 2007, given the inauspicious character of the international environment, but perhaps also because of each agency's expansion in other directions and reach towards other actors (UNHCR's broader promotion of livelihood and stronger linkages with NGOs on this issue, ILO's focus on domestic work). Cooperation between the UNHCR and ILO was weakened in this context.

It could be argued that the UNHCR's authority was left less diminished than that of the ILO in this particular field, even though the ILO is far less associated with refugee protection than the UNHCR. Since 2007, the UNHCR has increased its strategic focus on refugee livelihoods, while joint activities with the ILO were marginalized. The ILO did not rediscover the issue for itself, yet still appears as a knowledge provider in the field, even though this is barely visible at headquarter level. While the right to work has been affirmed within a number of projects, this is hard to say of rights at work, given the context. Increasing the organizational visibility of field activities focused on the refugee worker as well as normative entrepreneurship, as recommended in the 1983 $\mathrm{MoU}$, would certainly contribute to account for the political and multi-faceted nature of the socio-economic rights of refugees. ${ }^{67}$

Conceptually, the findings inform the critical study of migration management as they systematize factors that affect the authority of cooperating IOs, adding a stronger focus on how migration IOs work to Newland and Betts's analyses of competition and cooperation in global migration governance. ${ }^{68}$ The analysis also shows that Barnett and Finnemore's bureaucratic perspective on IOs not only helps to grasp the strengths and weaknesses of single IOs, but also explains how internal dynamics can impede promising joint initiatives. This is relevant not just for the study of the global migration governance architecture, but potentially for any area of global governance in which IOs pursue joint initiatives. Further research on IOs cooperation in auspicious and less auspicious international environments would help put the present case study in perspective and nurture conceptual questions, such as on the usefulness of particular bureaucratic pathologies for cooperation, how bureaucratic pathology in one IO can "infect" another IO via 
socialization in the context of joint projects, and whether IO cooperation can prevent bureaucratic pathologies.

\section{Notes}

1 Michael Barnett and Martha Finnemore, "The Politics, Power and Pathologies of International Organizations," International Organization 53 (1999): 699-732; Barnett and Finnemore, Rules for the World: International Organizations in Global Politics (Ithaca, NY: Cornell University Press, 2004).

2 Martin Geiger and Antoine Pécoud, "International Organisations and the Politics of Migration," Journal of Ethnic and Migration Studies 40 (2014): 865-87.

3 On the IOM see, for instance, Rutvica Andrijasevic and William Walters, "The International Organization for Migration and the International Government of Borders," Environment and Planning D: Society and Space 28 (2010): 977-99; on the UNHCR, Gil Loescher, "The UNHCR and World Politics: State Interests vs. Institutional Autonomy," International Migration Review 35 (2001): 33-56.

4 See Albert Thomas, "Albert Thomas on the International Control of Migration," Population and Development Review 9 (1983): 703-11; and Roger Bohning, "The ILO and the New UN Convention on Migrant Workers: The Past and Future," International Migration Review 25 (1991): 698-709; Antoine Pécoud and Paul de Gutcheneire, "Introduction: The UN Convention on Migrant Workers' Rights" in Pécoud and de Gutcheneire, Migration and Human Rights: The United Nations Conventions on Migrant Workers' Rights (Cambridge: Cambridge University Press, 2009); Juan M. Amaya-Castro, "Migration and the World of Work: Discursive Constructions of the Global in ILO Narratives about Migration," IMIS-Beiträge 40 (2012): 33-48.

5 International Labour Organization, "ILO and the Global Migration Group: Improving Global Migration Governance," ILO, 1 January 2014, http://www.ilo.org/global/ topics/labour-migration/WCMS_241411/lang--en/index .htm.

6 Kathleen Newland, "The Governance of International Migration: Mechanisms, Processes and Institutions," Global Governance 16 (2010): 331-43.

7 Alexander Betts, "Regime Complexity and International Organizations: UNHCR as a Challenged Institution," Global Governance, 19 (2013): 69-81.

8 Martin Geiger, Europäische Migrationspolitik und Raumproduktion. Internationale Regierungsorganisationen im Management von Migration in Albanien, BosnienHerzegowina und der Ukraine (Nomos: Baden-Baden, 2011).

9 Anne Koch, "The Politics and Discourse of Migrant Return: The Role of UNHCR and ILO in the Governance of Return," Journal of Ethnic and Migration Studies 40 (2014): 905-23.
10 Barnett and Finnemore, Rules for the World, 6.

11 Ibid., 8.

12 Barnett and Finnemore, Politics, Power and Pathologies, 720.

13 Barnett and Finnemore, Rules for the World, 163-6.

14 Penelope Mathew et al. "The Michigan Guidelines on the Right to Work," Michigan Journal of International Law 31 (2010): 293-306. Importantly, article 2(3) of the ICESCR allows developing countries to restrict the economic rights of foreign nationals "with due regard to human rights and their national economy."

15 The article will not conduct a historical analysis of the establishment of the UNHCR and the ILO, yet it can be noted that the United States and other Western countries opposed a greater role for the ILO in the protection of refugees after the Second World War; see Rieko Karatani, "How History Separated Refugee and Migrant Regimes: In Search of Their Institutional Origins," International Journal of Refugee Law 17 (2005): 517-41; Dzovinar Kévonian, "Les Réfugiés Européens et le Bureau International du Travail: Appropriation Catégorielle et Temporalité Transnationale (1942-1951)," in Humaniser le Travail, ed. Alya Aglan, Olivier Feiertag, and Dzovinar Kévonian, 167-94 (Brussels: Peter Lang, 2011); Katy Long, "When Refugees Stopped Being Migrants: Movement, Labour and Humanitarian Protection," Migration Studies 1 (2013): 15.

16 United Nations, United Nations Treaty Collection Database, Chapter V, Refugees and Stateless Persons, United Nations Geneva, https://reaties.un.org/pages/Treaties. aspx?id=5\&subid=A\&lang=eng.

17 The application of the UN Convention on the Rights of All Migrant Workers and Their Families is by the UN Committee on Migrant Workers, not supervised by the ILO. According to Bohning ("The ILO and the New UN Convention on Migrant Workers"), the existence of the convention apart from the ILO is due to the dissatisfaction of developing countries with the ILO's earlier migrant worker conventions, and their advocacy of a UN treaty. Nevertheless, the convention foresees a supervisory role for the ILO, which can participate in Committee on Migrant Workers meetings and express opinions on state reports to the committee; see Vincent Chetail, "The Committee on the Protection of the Rights of All Migrant Workers and Members of Their Families," in The United Nations and Human Rights: A Critical Appraisal, 2nd ed., ed. Philip Alston and Frederic Megret (Oxford: Oxford University Press, forthcoming). Chetail also writes that the Committee on Migrant Workers has addressed the rights to work of forced migrants on several occasions, noting that its interpretation of the boundaries between the Refugee Convention and the Migrant Workers Convention has so far been "confusing."

18 The right to work of asylum seekers is discussed in Bohning (ILO and the New UN Convention), Mathew et al. ("Michigan Guidelines"), and Chetail ("Committee on the 
Protection of the Rights"). This article focuses exclusively on recognized refugees.

19 See ILO Convention Co97, "Migration for Employment Convention," 1949, and ILO Convention C143, "Migrant Workers (Supplementary Provisions)," 1975.

20 As of August 2014, Co97 has been ratified by 49 countries, and $\mathrm{C} 143$ by 23 countries. See Bernhard Boockmann, Decision-Making on ILO Conventions and Recommendations: Legal Framework and Application, Documentation oo-03 (Mannheim: Zentrum für Europäische Wirtschaftsforschung, 2000); William R. Simpson, "StandardSetting and Supervision: A System in Difficulty," in Mélanges en l'Honneur de Nicolas Valticos, 47-73 (Geneva: International Labour Organisation, 2004). So far, this low level of ratification also applies to ILO Convention C189 on Domestic Workers adopted in 2011, and ratified by 14 countries as of August 2014.

21 Erica de Wet, "Governance through Promotion and Persuasion: The 1998 ILO Declaration on Fundamental Principles and Rights at Work," German Law Journal 9 (2008): 1429-52.

22 Eve Hall, With an Eye to the Future: ILO Refugee Programmes in Africa, ILO, InFocus Programme Working Paper 12 (Geneva: ILO, 2003); ILO Governing Body, Assessment of Selected ILO Projects concerning Migrants, Refugees and Displaced Persons, doc. GB.251/OP/2/1 (Geneva: ILO, 1991).

23 UN High Commissioner for Refugees and International Labour Organization, Memorandum of Understanding between the Director-General of the International Labour Organization and the United Nations High Commissioner for Refugees, published in Official Bulletin of the ILO, Vol. LXVII, 1984, Series A, No. 1. ILO Director General Blanchard had worked for the UNHCR's predecessor, the International Refugee Organization, and strongly advocated for the integration of competences over refugees in the ILO as he moved to the latter in 1951; see Kévonian, Les Refugiés Européens, 192.

24 UN High Commissioner for Refugees and International Organization for Migration, Memorandum of Understanding between the United Nations High Commissioner for Refugees and the International Organization for Migration (Geneva: UNHCR, 1997), http://www.refworld.org/ docid/3ae6b31a7o.html; UN High Commissioner for Refugees and World Food Programme, Memorandum of Understanding between the Office of the United Nations High Commissioner for Refugees and the World Food Programme (Geneva: UNCHR, 2002), http://www.refworld. org/docid/3d 357 f502.html.

25 Loescher, "UNHCR and World Politics."

26 Katherine A. Hagen, The International Labour Organization: Can It Deliver the Social Dimension of Globalization? (Geneva: Friedrich Ebert Foundation, 2003); Marieke Louis, L'Organisation Internationale du Travail et le Travail Décent (Paris: L'Harmattan, 2011); Francis Maupain,
The Future of the International Labour Organization in the Global Economy (Oxford: Hart, 2013).

27 International Labour Organization, ILO in Fragile Situations: An Overview (Geneva: ILO, 2014).

28 Betts, "Regime Complexity"; International Labour Organization, Independent Evaluation of the ILO Strategy to Improve the Protection of Migrant Workers, doc. GB.303/ $\mathrm{PFA} / 3 / 5$ (Geneva: Governing Body, ILO, 2004).

29 Michelle Azorbo, Microfinance and Refugees: Lessons Learned from UNHCR's Experience, Policy Development and Evaluation Services, New Issues in Refugee Research 199 (Geneva: UNHCR, 2011).

30 Ibid., 11.

31 International Labour Organization, Highlights: ILOUNHCR Partnership through Technical Cooperation (Geneva: ILO, 2004).

32 ILO-UNHCR Partnership through Technical Cooperation, Final Report: Self-Reliance and Sustainable Livelihood for Refugees in Dabaab and Kakuma Camps, MultiBilateral Programme of Technical Cooperation (Kakuma/ Dabaab: UNHCR, 2005); International Labour Organization, Strengthening Strategic Partnership for ILO's Crisis Response, ILO Evaluation Summaries (Geneva: ILO, 2005).

33 ILO-UNHCR Partnership through Technical Cooperation, Final Report; ILO-UNHCR Partnership through Technical Cooperation, Building Entrepreneurial Capacity for Returnee and Refugee Women in Angola and Mozambique (Geneva: ILO, 2006); ILO/CRISIS, The ILO-UNHCR Technical Cooperation Partnership, Employment for Peace Briefing Note 4 (Geneva: ILO, 2007); UN High Commissioner for Refugees, Global Report 2004 (Geneva: UNHCR, 2005), 74; UN High Commissioner for Refugees, "UNHCR Liberia," briefing note, 5 April 2005; UN High Commissioner for Refugees, Global Report 2005 (Geneva: UNHCR, 2006), 62; UN High Commissioner for Refugees, Global Report 2006 (Geneva: UNHCR, 2007), 46.

34 Eugenia Date-Bah, director, InFocus Programme on Crisis Response and Reconstruction, in Hall, With an Eye to the Future, iii. Further ILO publications on the work of the organization towards refugees in Central America and Asia were announced but never released.

35 ILO-UNHCR Partnership through Technical Cooperation, Building Entrepreneurial Capacity.

36 UN High Commissioner for Refugees, "UNHCR in Mozambique Gives Refugees the Skills to Be Self-Sufficient," news stories, 2 January 2007.

37 "ILO and UNHCR Partnership in Liberia," video interview, 16 May 2008, http://www.ilo.org/global/about-theilo/multimedia/video/video-interviews/WCMS_o93419/ lang--en/index.htm.

38 Ibid.

39 ILO/CRISIS, ILO-UNHCR Technical Cooperation Partnership.

40 ILO/UNHCR, Livelihood Programmes for Refugees: Executive Summary (Bangkok: UNHCR, n.d.); UN High 
Commissioner for Refugees, SPCP Thailand (Geneva: UNHCR, June 2008).

41 CCSDT-UNHCR, CCSDPT-UNHCR Strategic Framework: 2013 Progress Matrix, on file with author.

42 UN High Commissioner for Refugees, Global Strategy for Livelihoods: A UNHCR Global Strategy 2014-2018 (Geneva: UNHCR, 2014), 25.

43 Astri Surkhe and Arve Ofstad, "Filling the Gap": A Lesson Well-Learned by Multilateral Agencies, CMI Working Paper (Bergen: Chr. Michelsen Institute, 2005).

44 UN High Commissioner for Refugees, Summary Record of the 604th Meeting, doc. A/AC.96/SR.604, Executive Committee, UNHCR, 10 January 2008.

45 Suhrke and Ofstad, "Filling the Gap"; Bryan Deschamp and Sebastian Lohse, Still Minding the Gap? A Review of Efforts to Link Relief and Development in Situations of Human Displacement, 2001-2012, Policy Development and Evaluation Services, Evaluation 2013/o1 (Geneva: UNHCR, 2013): 33-9; Marjoleine Zieck, "Doomed to Fail from the Outset? UNHCR's Convention Plus Initiative Revisited," International Journal of Refugee Law 21 (2009): 387-420.

46 Deschamp and Lohse, Still Minding the Gap?, 7, 46.

47 ILO-UNHCR Partnership through Technical Cooperation, Final Report; Meredith Hunter, "The Failure of SelfReliance in Refugee Settlements," POLIS 2 (2009): 1-46.

48 "Mozambique: North Overwhelmed by Asylum-Seekers," IRINnews, 12 May 2011, http://www.irinnews.org/report /9269o/mozambique-north-overwhelmed-by-asylumseekers.

49 Adèle Garnier, "Migration Management and Humanitarian Protection: The UNHCR's 'Resettlement Expansionism' in the EU and Australia," Journal of Ethnic and Migration Studies 40 (2014): 942-59.

50 Robert E. B. Lucas, "Integrating Migration Issues into Development Planning," International Migration Programme, International Migration Working Papers 93 (Geneva: ILO, 2008).

51 Elizabeth Umlas, Cash in Hand: Urban Refugees, the Right to Work and UNHCR's Advocacy Activities, Policy and Evaluation Services and Operational Solutions and Transition Section, Evaluation Report 5/2011 (Geneva: UNHCR, 2011), 19-20.

52 Stefan Rother and Nicola Piper, "Let's Argue about Migration: Advancing a Right(s) Discourse via Communicative Opportunities," Third World Quarterly 33 (2011): 1735-50.

53 See Global Migration Group, http://www.globalmigrationgroup.org/gmg-documents.

54 UN System Chief Executive Board for Communication, International Migration and Development: Contributions and Recommendations of the International System (Geneva: United Nations System Chief Executive Board for Communication, 2013), chapters 5 and 21.

55 On the UNHCR, see Jennifer Hyndman, Managing Displacement: Refugees and the Politics of Humanitarianism (Minneapolis: Minnesota University Press, 2000);
Barb Wigley, The State of UNHCR's Organization Culture, Policy Evaluation and Analysis Unit, Evaluation Report EPAU/2005/08 (Geneva: UNHCR, 2005); on the ILO, Simpson, Standard-Setting and Supervision; Guy Standing, "The ILO: An Agency for Globalization?," Development and Change 39 (2008): 355-84.

56 Standing, "The ILO"; Simpson, Standard-Setting and Supervision.

57 ILO, Reports of the Director-General to the International Labour Conference, 89th and 92nd sessions (Geneva: ILO, 2001 and 2004).

58 Wigley, State of UNHCR's Organization Culture.

59 Ibid.

60 In October 2014, the ILO's International Training Centre presents the course "Decent Work for Domestic Workers," which targets trade unions representatives as much as state and international organizations officials working on the issue. See http://www.migration4development.org/ content/decent-work-domestic-workers. If the UNHCR sends a delegate, that may increase the likelihood of future joint activities on the topic.

61 See http://www.ilo.org/migrant/lang--eng/index.htm.

62 See, for instance, Aderanti Adepoju, "The Challenge of Labour Migration Flows between West Africa and the Maghreb," International Migration Programme, International Migration Papers 84 (Geneva: ILO, 2006).

63 Val Colic-Peisker, Bosnian Refugees in Australia: Identity, Community and Labour Market Integration, Evaluation and Policy Analysis Unit, New Issues in Refugee Research 97 (Geneva: UNHCR, 2003); Eleanor Ott, The Labour Market Integration of Resettled Refugees, Policy Development and Evaluation Services, Evaluation Report PDES/2013/16 (Geneva: UNHCR, 2013); Katy Long, Extending Protection? Labour Migration and Durable Solutions for Refugees, Policy Development and Evaluation Services, New Issues in Refugee Research 176 (Geneva: UNHCR, 2009); Umlas, Cash in Hand.

64 Asylum Access, "Requesting Action: Appeal to UNHCR to Increase Funding for Implementation of Livelihoods Objectives," 1 October 2013, Refugee Work Rights, http://rtwasylumaccess.wordpress.com/2013/10/o1/requesting-actionappeal-to-unhcr-to-increase-funding-for-implementation -of-livelihood-objectives/.

65 Scholarship is characterized by a debate over the greater openness of the ILO to grassroots migrant advocacy, which in the case of the UNHCR has been a vector of change. While Rother and Piper (Let's Argue about Migration) insist on the ILO's responsiveness to their concerns, arguing that this is due to its unique tripartite structure, Standing (The ILO: An Agency for Globalization) stresses the lack of representativeness of union staff elected within the ILO Governing Body as well as the wariness of unions towards non-union representation from civil society.

66 Roger Zetter, "Labelling Refugees: Forming and Transforming a Bureaucratic Identity," Journal of Refugee 
Studies 4 (1991): 39-62; Zetter, "More Labels, Fewer Refugees? Remaking the Refugee Label in an Era of Globalization," Journal of Refugee Studies 20 (2007): 172-92; Long, "When Refugees Stopped Being Migrants."

67 Raúl Delgado Wise, Humberto Márquez Covarrubias, and Ruben Puentes, "Reframing the Debate on Migration, Development and Human Rights," Population, Space and Place 19 (2013): 430-43.

68 Betts, "Regime Complexity"; Newland, "Governance of International Migration."
Adèle Garnier is a post-doctoral fellow at the Centre de Recherche Interuniversitaire sur la Mondialisation et le Travail (Interuniversity Research Centre on Globalization and Work), Montreal, and is affiliated with the Faculty of Law, Université de Montréal. She may be contacted at adele. garnier@umontreal.ca. are credited and the original publication in Refuge: Canada's Journal on Refugees is cited. 
(C) Adèle Garnier, 2014. This open-access work is licensed under a Creative Commons Attribution-NonCommercial 4.0 International License, which permits use, reproduction and distribution in any medium for non-commercial purposes, provided the original author(s) are credited and the original publication in Refuge: Canada's Journal on Refugees is cited. 